\title{
Influence of PEGylation of Vitamin-K-Loaded Mixed Micelles on the Uptake by and Transport through Caco-2 Cells
}

Feilong Sun, ${ }^{\dagger}$ Max Adrian, ${ }^{\ddagger}$ Nataliia Beztsinna, ${ }^{\dagger}$ Joep B. van den Dikkenberg, ${ }^{\dagger}$ Roel F. Maas-Bakker, ${ }^{\dagger}$ Peter M. van Hasselt, ${ }^{\S}$ Mies J. van Steenbergen, ${ }^{\dagger}$ Xiangjie Su, ${ }^{\dagger}$ Lukas C. Kapitein, ${ }^{\ddagger}{ }^{\ddagger}$ Wim E. Hennink, ${ }^{\dagger}$ and Cornelus F. van Nostrum* ${ }^{*}+$ (i)

${ }^{\dagger}$ Department of Pharmaceutics, Utrecht Institute for Pharmaceutical Sciences, Utrecht University, 3584 CG Utrecht,

The Netherlands

${ }^{\ddagger}$ Cell Biology, Department of Biology, Faculty of Science, Utrecht University, $3584 \mathrm{CH}$ Utrecht, The Netherlands

${ }^{\S}$ Department of Pediatrics, Wilhelmina Children's Hospital, University Medical Center Utrecht, Lundlaan 6, 3584 EA Utrecht, The Netherlands

\section{Supporting Information}
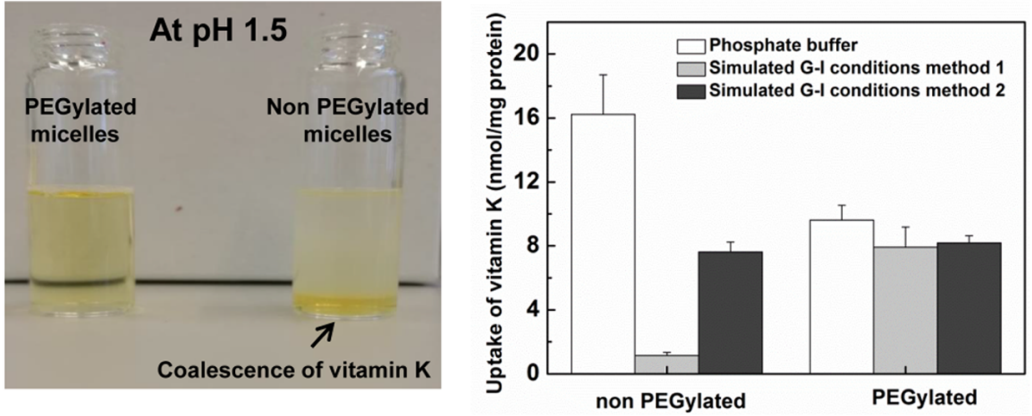

ABSTRACT: The aim of the study is to investigate the uptake by and transport through Caco-2 cells of two mixed micelle formulations (based on egg phosphatidylcholine and glycocholic acid) of vitamin K, i.e., with and without DSPE-PEG2000. The uptake of vitamin $\mathrm{K}$ and fluorescently labeled mixed micelles with and without PEG coating showed similar kinetics and their uptake ratio remained constant over time. Together with the fact that an inhibitor of scavenger receptor B1 (BLT-1) decreased cellular uptake of vitamin $\mathrm{K}$ by $\sim 80 \%$ compared to the uptake in the absence of this inhibitor, we conclude that both types of micelles loaded with vitamin $\mathrm{K}$ can be taken up intactly by Caco- 2 cells via this scavenger receptor. The amount of vitamin $\mathrm{K}$ in chylomicrons fraction from Caco-2 cell monolayers further indicates that mixed micelles (with or without PEGylation) are likely packed into chylomicrons after internalization by Caco- 2 cells. Uptake of vitamin $\mathrm{K}$ from PEGylated mixed micelles increased four- to five-fold at simulated gastrointestinal conditions. In conclusion, PEGylated mixed micelles are stable upon exposure to simulated gastric conditions, and as a result, they do show overall a higher cellular uptake efficiency of vitamin $\mathrm{K}$ as compared to mixed micelles without PEG coating.

KEYWORDS: mixed micelles, PEGylation, Konakion MM, vitamin K, Caco-2

\section{INTRODUCTION}

Newborns can be deficient in vitamin $\mathrm{K}$ due to the limited transport of this vitamin through the placental barrier and low concentration in breast milk. ${ }^{1}$ Since deficiency of this vitamin may result in spontaneous life-threatening hemorrhages, newborns therefore routinely receive oral vitamin $\mathrm{K}$ prophylaxis to prevent vitamin $\mathrm{K}$ deficiency bleeding (VKDB). In healthy individuals, orally administered vitamin $\mathrm{K}$ is emulsified by naturally occurring bile salts to form mixed micelles together with phospholipids, to facilitate the transfer of vitamin $\mathrm{K}$ and other lipophilic vitamins through the mucus layer before being taken up by enterocytes. ${ }^{2}$ However, newborns with cholestasis, whose flow of bile from the liver is slowed down or blocked, are at higher risk of developing VKDB despite receiving this prophylaxis. ${ }^{3}$ Indeed, more than $80 \%$ of infants with cholestasis developed VKDB. ${ }^{3}$ A clinical trial in patients with cholestasis showed that the absorption of vitamin $\mathrm{K}$ after oral administration of Konakion MM (a clinically used mixed micelle formulation containing glycocholic acid) was low and showed high patient variability. ${ }^{4}$ Recent studies have elucidated a possible reason for the failure of Konakion MM to prevent VKDB in infants with cholestasis. ${ }^{4,5}$ Glycocholic acid is one of the components of Konakion MM and has a carboxylic acid group

Received: March 12, 2018

Revised: June 14, 2018

Accepted: July 31, 2018

Published: July 31, 2018 
with a $\mathrm{p} K_{\mathrm{a}}$ of $3.8,{ }^{6}$ which ensures, due to charge repulsion, a good colloidal stability of the formulation at $\mathrm{pH}>4$. However, the formulation is unstable and aggregates at low gastric $\mathrm{pH}$ because of the protonation of the carboxylate group of glycocholic acid, causing coalescence of the micelles. ${ }^{7}$ In patients with cholestasis, the extreme low level of bile salts in the small intestine prevents coalesced vitamin $\mathrm{K}$ from being resolubilized resulting in an impaired absorption. ${ }^{4,5}$

In our previous study, a PEGylated lipid (DSPE-PEG 2000) was introduced as a micellar component to improve the colloidal stability of the formulation at low $\mathrm{pH} .{ }^{8}$ It was shown that mixed micelles (PEGylated or non-PEGylated) of around 7 to $11 \mathrm{~nm}$ were obtained by a convenient film hydration method followed by triple membrane extrusion. Importantly, coalescence of the formulation at gastric $\mathrm{pH}$, as observed for Konakion MM, was avoided most likely through steric stabilization by DSPE-PEG 2000 in the micelles (size of PEGylated micelles remained $10 \mathrm{~nm}$ upon incubation at gastric low $\mathrm{pH}$ ). Therefore, the PEGylated micelles are expected to arrive intactly in the duodenum. To our knowledge, although the absorption of vitamin $\mathrm{K}$ loaded in polymeric micelles, lipid based vehicles, and emulsions has been investigated, ${ }^{9-11}$ cellular uptake and transport of vitamin $\mathrm{K}$ loaded in small sized mixed micelles $(<15 \mathrm{~nm})$ that are stable at low gastric $\mathrm{pH}$ have not been reported before. In this study, Caco- 2 cells were used as intestinal epithelium model. This human colorectal adenocarcinoma cell line is frequently used for drug absorption studies because these cells have the capability to spontaneously differentiate into cells possessing the morphology and function of enterocytes. $^{12}$ Therefore, the objective of the current study was to investigate the influence of PEGylation of mixed micelles on the extent and mechanism of cellular uptake of vitamin $\mathrm{K}$ and to investigate this in simulated gastrointestinal environment mimicking the pathological condition of cholestasis.

\section{EXPERIMENTAL SECTION}

The following methods sections are included in the Supporting Information: Preparation of mixed micelles; size measurements; quantification of the fluorescent probes in the formulations; quantification of vitamin K by HPLC; quantification of protein; uptake of micelles by undifferentiated Caco-2 cells; Western blot analyses of scavenger receptor B1 and NiemannPick C1-like 1 (NPC1L1) expression in Caco-2 cells; measurement of trans-epithelial electro resistance (TEER); determination of the extraction efficiency of vitamin $\mathrm{K}$.

Materials. Lecithin (egg phosphatidylcholine, EPC) and 1,2-distearoyl-sn-glycero-3-phosphoethanolamine- $N$-[methoxy(polyethylene glycol)] (molecular weight of PEG $=2 \mathrm{kDa}$, DSPE-PEG 2000) were purchased from Lipoid $\mathrm{GmbH}$ (Ludwigshafen, Germany). Block lipid transport-1 (BLT-1), Ezetimibe, potassium phosphate monobasic $\left(\mathrm{KH}_{2} \mathrm{PO}_{4}\right)$, and sodium phosphate dibasic dihydrate $\left(\mathrm{Na}_{2} \mathrm{HPO}_{4} \cdot 2 \mathrm{H}_{2} \mathrm{O}\right)$ were purchased from Sigma-Aldrich (Zwijndrecht, The Netherlands) and used to prepare $0.067 \mathrm{M}$ phosphate buffer $(2.5 \mathrm{mmol}$ of $\mathrm{KH}_{2} \mathrm{PO}_{4}$ and $4.2 \mathrm{mmol}$ of $\mathrm{Na}_{2} \mathrm{HPO}_{4} \cdot 2 \mathrm{H}_{2} \mathrm{O}$ in $100 \mathrm{~mL}$ of reverse osmosis water, $\mathrm{pH}$ 7.3). Sodium chloride, sodium hydroxide, ZnAc, and ethanol were purchased from Merck KGaA (Darmstadt, Germany). 1,2-Dioleoyl-sn-glycero-3-phosphoethanolamine- $N$-(lissamine rhodamine B sulfonyl) (rhodamine conjugated PE) and fluorescein-labeled 1,2-distearoyl$s n$-glycero-3-phosphoethanolamine- $\mathrm{N}$-[methoxy (polyethylene glycol)] (molecular weight 2000, DSPE-PEG-fluorescein) were obtained from Avanti Polar Lipid, Inc. Chloroform was provided by Biosolve (Valkenswaard, The Netherlands). Hoechst dye 33342 was bought from Molecular Probes (Eugene, OR, USA). High glucose (4.5 g/L) Dulbecco's modified Eagle's medium (DMEM), fetal bovine serum (FBS), Hank's balanced salt solution (HBSS), pepsin from porcine stomach mucosa, vitamin $\mathrm{K}$, glycocholic acid hydrate, and all other chemicals and reagents were purchased from Sigma-Aldrich (Zwijndrecht, The Netherlands). Konakion MM was a product manufactured by Roche (Basel, Switzerland). All chemicals and solvents were used without further purification.

Caco-2 Cell Culture. Caco-2 cells were cultured in Dulbecco's modified Eagle's medium (DMEM, Sigma-Aldrich) supplemented with $10 \%$ fetal bovine serum (FBS, SigmaAldrich). For transport experiments, the medium was further supplemented with $100 \mathrm{U} / \mathrm{mL}$ penicillin and $100 \mathrm{U} / \mathrm{mL}$ streptomycin to prevent bacterial growth during the measurement of TEER values (Supporting Information section 1.8) and 1\% nonessential amino acids. The culture flasks and the transwell plates were placed in an incubator at $37{ }^{\circ} \mathrm{C}$ with $5 \% \mathrm{CO}_{2}$.

Uptake Kinetics of Rhodamine-DSPE Labeled Mixed Micelles and Vitamin $\mathrm{K}$ by Caco-2 Cells. Caco- 2 cells were seeded at a density of $1 \times 10^{5}$ cells per well in a 96-well plate 3 weeks before the uptake study and cultured as described in Caco-2 Cell Culture to obtain a confluent monolayer of differentiated cells. Rhodamine-PE labeled vitamin-K-loaded mixed micelles in blank DMEM (PEGylated or non-PEGylated) (150 $\mu \mathrm{L}, 2.5 \mu \mathrm{M}$ rhodamine-PE) were added to the cells and incubated for $0.5,2$, and $4 \mathrm{~h}$, respectively. Subsequently, the liquids were removed, and the monolayers of Caco- 2 cells were washed 3 times with PBS and exposed to Hoechst dye 33342 ( $5 \mu \mathrm{M}$ in $150 \mu \mathrm{L}$ of blank DMEM) for $20 \mathrm{~min}$ to stain the nuclei of Caco- 2 cells. Images were acquired using CV 7000 high content imaging system (Yokogawa Electric Corporation, Tokyo, Japan) with excitation at $405 \mathrm{~nm}$ (nuclei staining), $488 \mathrm{~nm}$ (fluorescein staining), and $561 \mathrm{~nm}$ (rhodamine staining) at $60 \times$ water immersion objective.

Uptake kinetics of vitamin $\mathrm{K}$ from 0.5 to $4 \mathrm{~h}$ was investigated at a concentration of $0.56 \mathrm{mM}$ vitamin $\mathrm{K}$ (PEGylated or non-PEGyated in blank DMEM). After exposure to the micelles, cells were washed three times with PBS and subsequently exposed to RIPA lysis buffer $(150 \mathrm{mM} \mathrm{NaCl}, 1.0 \%$ Triton X-100, 1\% sodium deoxycholate, $0.1 \%$ SDS, $50 \mathrm{mM}$ Tris-HCl, $2 \mathrm{mM}$ EDTA, $\mathrm{pH} 8.0$ ) for $10 \mathrm{~min}$ at $37^{\circ} \mathrm{C}$ to obtain cell lysates, which were analyzed with micro BCA protein assay kit (Thermo Fisher Scientific, Perbio Science Nederland B.V.) and HPLC to obtain the total amount of protein and vitamin K, respectively (see Supporting Information sections 1.4 and 1.5).

Uptake of Mixed Micelles by Caco-2 Cells As Studied by Fluorescence Activated Cell Sorting Analysis (FACS). Caco- 2 cells were seeded in a 24-well plate at a density of $1 \times$ $10^{5}$ cells per well and cultured for 3 weeks as described in Caco-2 Cell Culture. Subsequently, the monolayers of Caco-2 cells were washed with PBS, and $200 \mu \mathrm{L}$ of non-PEGylated or PEGylated mixed micelles loaded with vitamin $\mathrm{K}(1.4 \mathrm{mM})$ and labeled with fluorescein-DSPE-PEG was added. Fluorescein conjugated DSPE-PEG labeled mixed micelles were used for fluorescence activated cell sorting analysis (FACS) (FACSCalibur; BD Biosciences) because the FACS instrument has a specific FITC channel. After incubation for $2 \mathrm{~h}$ at 4 and $37{ }^{\circ} \mathrm{C}$, respectively, the medium was removed, and the cells were washed three times with PBS. Subsequently, $90 \mu \mathrm{L}$ of solution of $0.02 \%$ EDTA and $0.05 \%$ trypsin solutions (Sigma) were added to detach the cells from the wells, and after $10 \mathrm{~min}$, 
$200 \mu \mathrm{L}$ of PBS was added to suspend the cells. The obtained cell suspensions were centrifuged for $5 \mathrm{~min}$ at $400 \times g$. The supernatants were removed, and $200 \mu \mathrm{L}$ of PBS was added to resuspend the cells. The cell suspensions were subsequently analyzed by FACS using the FITC channel. The mean fluorescence signal in six quadrants was analyzed using FlowJo software based on 10,000 cells. Caco- 2 cells treated with PBS were used as a control.

Effect of Inhibitors of Scavenger Receptor B1 and NPC1L1 on the Uptake of Vitamin K Loaded in Mixed Micelles. BLT-1 was dissolved in DMSO at different concentrations of $0.1,0.5$, and $2.0 \mathrm{mM}$, respectively. Subsequently, the solutions were diluted 200 times with blank DMEM to 0.5 , 2.5 , and $10 \mu \mathrm{M}$, respectively. Ezetimibe was dissolved in DMSO at different concentrations of 4,8 , and $20 \mathrm{mM}$, respectively. Subsequently, the solutions of ezetimibe were diluted 200 times with blank DMEM to 20,40 , and $100 \mu \mathrm{M}$, respectively. Cells were preincubated with $150 \mu \mathrm{L}$ of BLT-1 or ezetimibe at above different concentrations for $1 \mathrm{~h}$ at $37{ }^{\circ} \mathrm{C}$, and subsequently, $150 \mu \mathrm{L}$ samples of the different mixed micelle formulations (compositions are described in Supporting Information section 1.1) were incubated with the cells for $2 \mathrm{~h}$ at $37^{\circ} \mathrm{C}$. Subsequently, mixed micelles were removed, and the cells were washed three times with PBS. Trypsin/EDTA $(200 \mu \mathrm{L}, 5 \mathrm{~g} / \mathrm{L}$ trypsin, and $2 \mathrm{~g} / \mathrm{L}$ EDTA, Sigma) was added and incubated for $30 \mathrm{~min}$ to detach cells, and $400 \mu \mathrm{L}$ of RIPA buffer $(150 \mathrm{mM}$ $\mathrm{NaCl}, 1.0 \%$ Triton $\mathrm{X}-100,1.0 \%$ sodium deoxycholate, $0.1 \%$ SDS, $50 \mathrm{mM}$ Tris-HCl, $2 \mathrm{mM}$ EDTA, $\mathrm{pH}$ 8.0) was added to the wells to lyse the cells. The cell lysates were stored in $-20{ }^{\circ} \mathrm{C}$ before quantification of vitamin $\mathrm{K}$ uptake as in Supporting Information sections 1.4 and 1.5 .

Separation of Chylomicrons from Caco-2 Cells. Caco-2 cells were cultured in a 24-well plate at a density of $1 \times 10^{5}$ cells per well for 3 weeks as described in Caco-2 Cell Culture. Caco- 2 cell monolayers were incubated for $1 \mathrm{~h}$ with $200 \mu \mathrm{L}$ of Hank's balanced salt solution (HBSS, pH 7.4, $137 \mathrm{mM} \mathrm{NaCl}$, $5.4 \mathrm{mM} \mathrm{KCl}, 0.25 \mathrm{mM} \mathrm{Na}_{2} \mathrm{HPO}_{4}, 5.55 \mathrm{mM}$ glucose, $0.44 \mathrm{mM}$ $\mathrm{KH}_{2} \mathrm{PO}_{4}$, and $4.2 \mathrm{mM} \mathrm{NaHCO} 3$ ) supplemented with $25 \mathrm{mM}$ HEPES, $40 \mathrm{mg} / \mathrm{mL}$ BSA, $0.5 \mathrm{mM}$ taurocholate, and $2 \mathrm{mM}$ oleic acid. Oleic acid was added to enhance the formation of chylomicrons because oleic acid can influence secretion of chylomicrons by Caco-2 cells. ${ }^{13,14}$ Next, HBSS was removed, and $400 \mu \mathrm{L}$ of mixed micelles (with and without PEG coating, at $1.4 \mathrm{mM}$ vitamin $\mathrm{K}$ in blank DMEM) was incubated with the cells for $2 \mathrm{~h}$. Subsequently, the cells were washed three times with PBS and incubated with trypsin/EDTA $(200 \mu \mathrm{L})$ to detach the cells. PBS $(400 \mu \mathrm{L})$ was added to the wells to obtain homogeneous cell suspensions. Subsequently, the cells from two wells were pooled, and the cell suspensions were centrifuged at $300 \times g$ for $5 \mathrm{~min}$. Subsequently, the supernatants were removed, and the cells were suspended in $1.2 \mathrm{~mL}$ of PBS. Next, the cell suspensions were subjected to three freeze-thaw cycles by being immersed in liquid nitrogen/ice cold water to lyse the cells (RIPA buffer was not used because detergents from RIPA buffer may destroy chylomicrons). Subsequently, the samples were centrifuged at $300 \times g$ for $5 \mathrm{~min}$ to remove cellular debris, and samples of the supernatants $(20 \mu \mathrm{L})$ were analyzed to determine the amount of protein as described in Supporting Information section 1.5. The supernatants $(1 \mathrm{~mL})$ were added to $9 \mathrm{~mL}$ of $3.4 \mathrm{M} \mathrm{NaCl}$ solution to obtain dispersions with a density of $1.2 \mathrm{~g} / \mathrm{mL}$. Next, reverse osmosis water $(500 \mu \mathrm{L})$ was gently put on top of the samples to have two layers due to their different density, and the intracellular chylomicrons (with a density $<0.95 \mathrm{~g} / \mathrm{mL}$ ) ${ }^{15}$ were separated by ultracentrifugation at $10,000 \mathrm{rpm}$ for $30 \mathrm{~min}$ according to the method of Nauli et al. (Optima L-90K Ultracentrifuge, Beckman Coulter, Inc.). ${ }^{13}$ The water layer $(400 \mu \mathrm{L})$ on the top that contained the chylomicrons was collected and homogenized. Subsequently, $20 \mu \mathrm{L}$ was diluted with $60 \mu \mathrm{L}$ of PBS, and the amount of $\mathrm{ApoB}_{48}$ (from the chylomicrons) was quantified using a sandwich ELISA kit according to the manufacturer's protocol (Bio-Connect Diagnostics BV, Huissen, The Netherlands). To measure the vitamin $\mathrm{K}$ content in the same water layer that contained the chylomicrons, $50 \mu \mathrm{L}$ sample of the same water layer on the top was added to $450 \mu \mathrm{L}$ of ethanol, and the samples were vortexed for $1 \mathrm{~min}$ and then centrifuged at $8000 \mathrm{rpm}$ for $10 \mathrm{~min}$. Samples of the supernatants $(100 \mu \mathrm{L})$ were analyzed by HPLC to measure the amount of vitamin $\mathrm{K}$ as described in Supporting Information section 1.4. The collected chylomicrons dispersion ( $10 \mu \mathrm{L}$, from the top layer) after ultracentrifugation was studied by transmission electron microscopy (TEM, Tecnai 10, Philips, and $100 \mathrm{kV}$ ) using the same approach as described in our previous publication.

Transport of Vitamin-K-Loaded Mixed Micelles through Caco-2 Cells. Caco- 2 cells were seeded on a polyester membrane with $0.4 \mu \mathrm{m}$ pore size (Transwell, 24-well, Corning) at a density of $1 \times 10^{5}$ cells per insert and grown for 3 weeks. ${ }^{16,17}$ One milliliter of supplemented HBSS (composition given in Separation of Chylomicrons from Caco-2 Cells) was added to the basolateral side of the transwell. Next, $200 \mu \mathrm{L}$ of blank HBSS was added to the apical side of the transwell, and the cells were incubated for $1 \mathrm{~h}$ at $37^{\circ} \mathrm{C}$. Subsequently, the medium from the apical side of the transwell was removed. Next, the cells were washed three times with PBS and replaced with donor solution $(200 \mu \mathrm{L}$ of mixed micelle dispersions in blank HBSS, at a concentration of $1.4 \mathrm{mM}$ vitamin $\mathrm{K}$ ). Samples $(500 \mu \mathrm{L})$ were withdrawn from the basolateral side of the transwell at different time points $(30,60,90,120,150,180$, and $210 \mathrm{~min}$ ) and replaced by the same volume of abovementioned supplemented HBSS.

A sample of the basolateral medium $(200 \mu \mathrm{L})$ was transferred into a $1.5 \mathrm{~mL}$ polypropylene tube, and $300 \mu \mathrm{L}$ of ethanol was added to precipitate the proteins with brief agitation. After being vortexed for $1 \mathrm{~min}, 0.75 \mathrm{~mL}$ of $n$-hexane was added, and the contents were mixed vigorously. The samples were centrifuged for $10 \mathrm{~min}$ at $8000 \mathrm{rpm}$ at room temperature to separate the upper hexane layer from the lower water/ ethanol layer and precipitated proteins. The upper hexane layer was quantitatively transferred into a disposable glass tube. The lower layer was extracted with another $0.75 \mathrm{~mL}$ of hexane as described above. The above two hexane layers were pooled and evaporated to dryness under vacuum at room temperature. Next, $200 \mu \mathrm{L}$ of mobile phase (see Supporting Information section 1.4) was added, the samples were vortexed for $2 \mathrm{~min}$, and subsequently, $100 \mu \mathrm{L}$ of the above sample was injected onto the HPLC column and analyzed as described in Supporting Information section 1.4.

Uptake of Vitamin-K-Loaded Mixed Micelles by Caco-2 Cells under Simulated Gastrointestinal Conditions. To mimic cholestatic in vivo conditions, fasted simulated gastric fluid (FaSSGF, $20.0 \mu \mathrm{M}$ lecithin, $34.2 \mathrm{mM} \mathrm{NaCl}$, and $0.1 \mathrm{mg} / \mathrm{mL}$ pepsin) and intestinal fluid without bile salt (FaSSIF, $0.8 \mathrm{mM}$ EPC, $106.0 \mathrm{mM}$ sodium chloride, and $25.4 \mathrm{mM}$ sodium phosphate monobasic) were prepared according to a previous publication. ${ }^{18}$ Non-PEGylated micelles $(1.50 \mathrm{~mL})$ or 

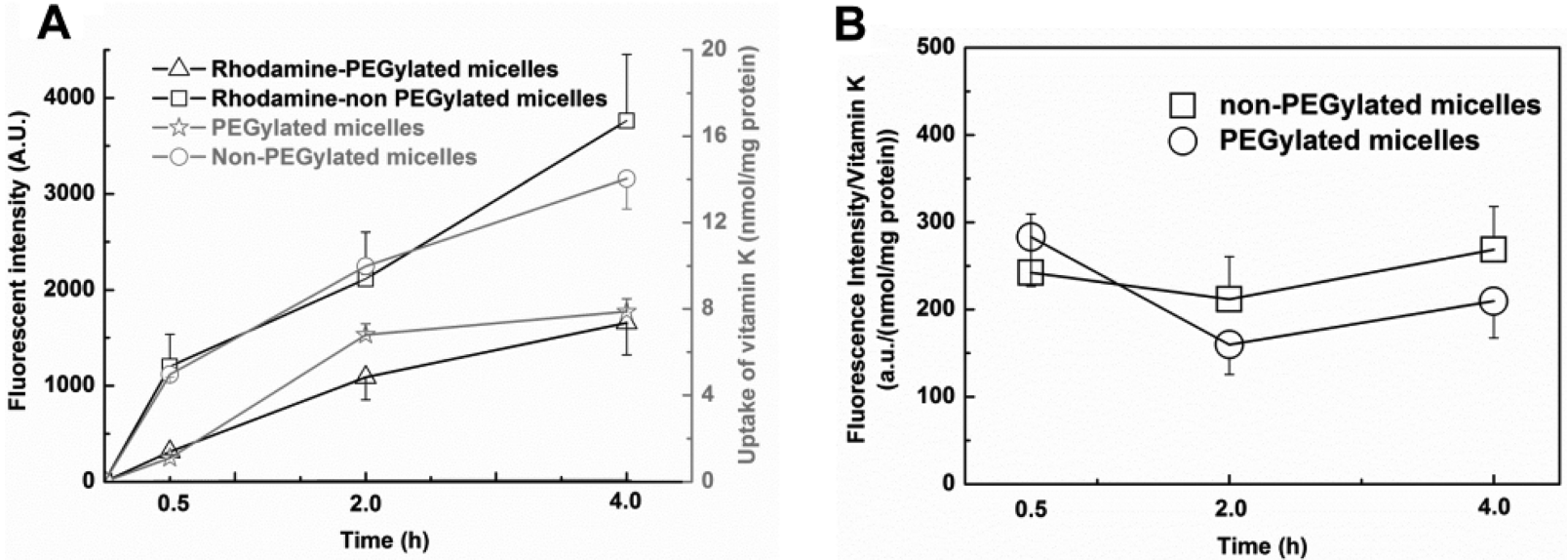

Figure 1. (A) Fluorescence intensity of rhodamine signal shown in rhodamine channel from confocal laser scanning microscopy pictures of Supplemental Figure S2 at different incubation times $(0.5,2.0$, and $4.0 \mathrm{~h}$ ) (black, left $y$-axis) and time-dependent uptake of vitamin $\mathrm{K}$ upon incubation of Caco-2 cells with mixed micelles (non-PEGylated and PEGylated micelles) at $37{ }^{\circ} \mathrm{C}$ and at a concentration of $0.56 \mathrm{mM}$ vitamin $\mathrm{K}$ (gray, right $y$-axis). (B) Uptake ratio (defined as rhodamine fluorescence intensity divided by the correlating uptake of vitamin $\mathrm{K}$ ) at different time points from 0.5 to $4.0 \mathrm{~h}$.

PEGylated micelles with $5.6 \mathrm{mM}$ vitamin $\mathrm{K}$ were added to $0.75 \mathrm{~mL}$ of FaSSGF, and $0.24 \mathrm{~mL}$ of a $1 \mathrm{M} \mathrm{HCl}$ solution was added to yield a $\mathrm{pH}$ of 1.5 . The dispersions were incubated for $1 \mathrm{~h}$ at $37^{\circ} \mathrm{C}$ with slow rotating at $50 \mathrm{rpm}$ on a rotary shaker in an incubator (Binder, Germany). Subsequently, $0.75 \mathrm{~mL}$ of FaSSIF and $0.24 \mathrm{~mL}$ of a $1 \mathrm{M} \mathrm{NaOH}$ solution (to yield a $\mathrm{pH}$ of 6.5) was added, and the dispersions were incubated for $1 \mathrm{~h}$ at $37{ }^{\circ} \mathrm{C}$ (not on a rotary shaker, but rotated manually every $20 \mathrm{~min}$ ). Subsequently, two methods were applied to collect samples to analyze the amount of vitamin $\mathrm{K}$ before incubation with Caco- 2 cells. Method 1, $0.5 \mathrm{~mL}$ of dispersions of the top layer (without disturbing the precipitated vitamin $\mathrm{K}$ at the bottom) was diluted with blank DMEM $(0.38 \mathrm{~mL})$; Method 2, dispersions were vortexed for $1 \mathrm{~min}$; subsequently, dispersions of $0.5 \mathrm{~mL}$ were diluted with blank DMEM $(0.38 \mathrm{~mL})$. As a control, mixed micelles $(1.50 \mathrm{~mL}, 5.6 \mathrm{mM}$ vitamin $\mathrm{K})$ were diluted with $1.98 \mathrm{~mL}$ of phosphate buffer $(0.067 \mathrm{M}, \mathrm{pH} 7.3)$, and the samples $(0.5 \mathrm{~mL})$ were diluted with blank DMEM $(0.38 \mathrm{~mL})$. Subsequently, Caco- 2 cell monolayers (that were seeded in a 24-well plate at a density of $1 \times 10^{5}$ cells per well and cultured for 3 weeks as described in Caco-2 Cell Culture) were incubated with the different samples for $2 \mathrm{~h}$ at $37^{\circ} \mathrm{C}$. Subsequently, the cells were washed three times with PBS and subsequently exposed to RIPA buffer to obtain cell lysates that were analyzed by micro BCA protein assay kit and HPLC for protein and vitamin $\mathrm{K}$ concentration, respectively, as described in Supporting Information sections 1.4 and 1.5.

Statistical Analysis. Statistical analysis was performed using Prism 7.0 software (GraphPad Software Inc.). KurskalWallis test with Dunn's multiple comparisons test $(* * * p<$ 0.0001 ) was used as indicated in the figure legends.

\section{RESULTS}

Uptake of Vitamin-K-Loaded Mixed Micelles by Caco-2 Cells. Details of the preparation and characterization (size and composition) of the micelles with or without DSPE-PEG can be found in the Supporting Information sections 1.1, 1.2, 1.3, 2.1, Figure S1, and Table S1. Vitamin-K-loaded micelles had hydrodynamic diameters of around $10 \mathrm{~nm}$. The effect of PEGylation on the uptake kinetics of the vitamin $\mathrm{K}$ loaded mixed micelles was investigated. Both the uptake of fluorescently labeled lipid (rhodamine-PE, Supplemental Figure S2) and vitamin K (Supplemental Figure S3) were significantly higher when loaded in non-PEGylated micelles than in PEGylated micelles (as summarized in Figure 1A). The uptake of fluorescently labeled micelles and vitamin $\mathrm{K}$ showed similar kinetics and their uptake ratio (defined as rhodamine fluorescence intensity divided by the correlating uptake of vitamin K) remained constant (around $220 \mathrm{au} /(\mathrm{nmol} / \mathrm{mg}$ protein) for both non-PEGylated and PEGylated micelles, see Figure 1B).

Receptor Mediated Uptake of Vitamin-K-Loaded Mixed Micelles by Caco-2 Cells. To investigate whether the uptake pathway of vitamin-K-loaded mixed micelles is energy dependent, they were labeled with fluorescein-DSPEPEG, and cellular uptake was evaluated by FACS at both 4 and $37^{\circ} \mathrm{C}$. After $2 \mathrm{~h}$ of incubation at $37^{\circ} \mathrm{C}$, the amount of vitamin $\mathrm{K}$ taken up by or associated with cells was concentration dependent: when the concentration of vitamin $\mathrm{K}$ increased from 0.22 to $1.40 \mathrm{mM}$, association increased from $6.8 \pm 0.7$ to $16.2 \pm$ $2.5 \mathrm{nmol} / \mathrm{mg}$ protein for non-PEGylated micelles and from $3.4 \pm 0.8$ to $9.6 \pm 0.9 \mathrm{nmol} / \mathrm{mg}$ protein for PEGylated mixed micelles, respectively (Figure $2 \mathrm{~A}$ ). Totals of $86.8 \pm 2.9$ and $97.1 \pm 1.7 \%$ of the cells were associated with fluorescence from PEGylated micelles and non-PEGylated micelles, respectively (Figure 2B). At $4{ }^{\circ} \mathrm{C}$, these values decreased to $7.0 \pm 2.5$ and $37.4 \pm 7.8 \%$, respectively (Figure $2 \mathrm{~B}$ ), while uptake was still concentration dependent (Supplemental Figure S3). The inhibition of uptake of fluorescently labeled micelles (Figure 2C) and vitamin $\mathrm{K}$ at $4{ }^{\circ} \mathrm{C}$, as compared to $37{ }^{\circ} \mathrm{C}$, would indicate that the uptake mechanism is carrier mediated ${ }^{19}$ because carriermediated processes are energy dependent and thus minimal at $4{ }^{\circ} \mathrm{C} .{ }^{20,21}$ The uptake of fluorescein-labeled mixed micelles by undifferentiated Caco- 2 cells, which are not grown to confluency, was also significantly lower at $4{ }^{\circ} \mathrm{C}$ than that at $37{ }^{\circ} \mathrm{C}$ after $2 \mathrm{~h}$ of incubation (Supplemental Figure S4B/C), suggesting that the involved carriers were also present in these undifferentiated cells.

Two receptors have previously been suggested as being involved in vitamin $\mathrm{K}$ uptake, i.e., scavenger receptor $\mathrm{B} 1$ protein and NPC1L1 protein. ${ }^{10,22}$ Western blot analysis with $\beta$-actin as a reference was used to confirm whether these 

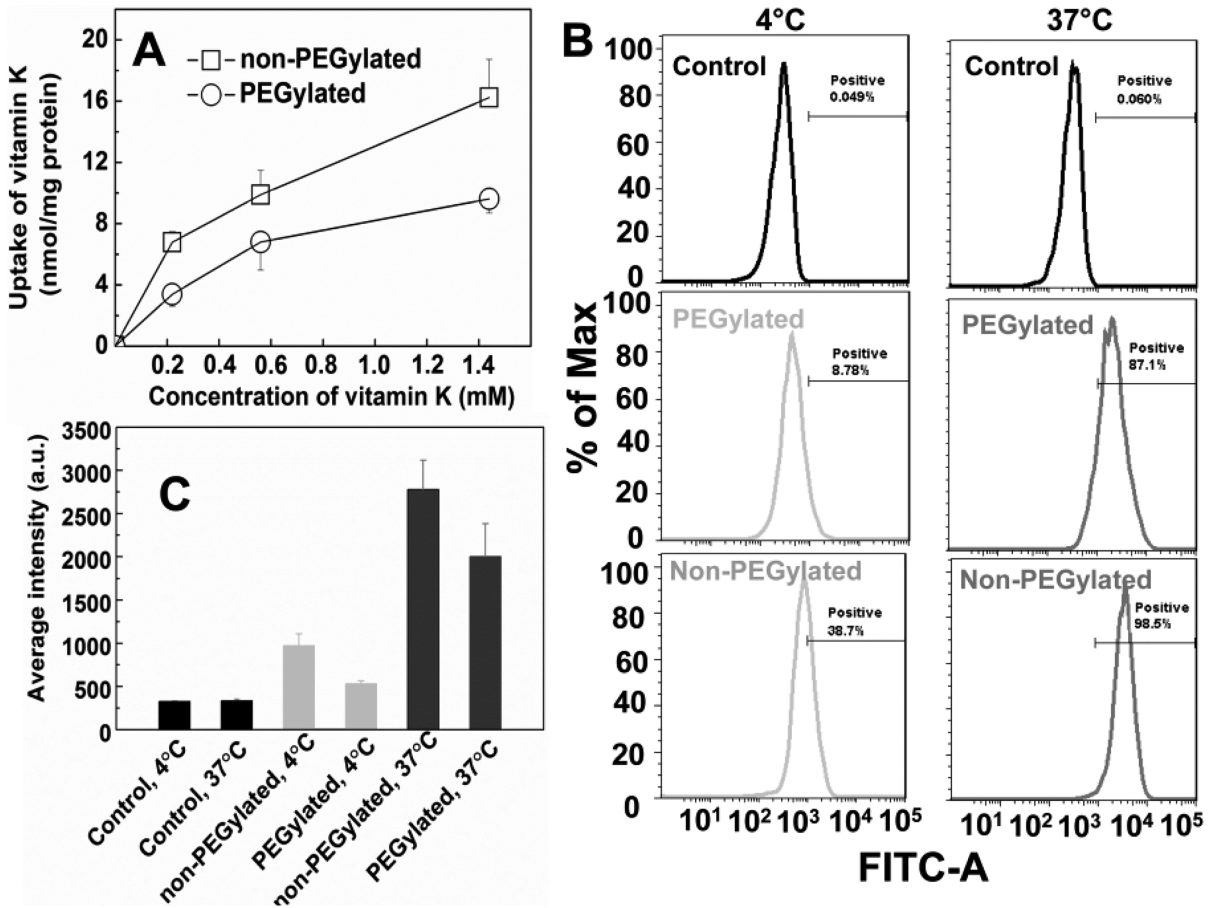

Figure 2. (A) Uptake of vitamin $\mathrm{K}$ upon incubation of Caco-2 cells with mixed micelles of two different compositions (PEGylated and nonPEGylated) at different concentrations of vitamin $\mathrm{K}(0.22,0.56$, and $1.40 \mathrm{mM})$ after $2 \mathrm{~h}$ at $37^{\circ} \mathrm{C}$; results are expressed as mean $\pm \mathrm{SD}(n=3)$. (B) FACS histograms of Caco-2 cells exposed to PBS (controls), and fluorescein-DSPE-PEG labeled non-PEGylated and PEGylated micelles; results from one representative experiment are shown. (C) Corresponding mean fluorescence intensities are expressed as mean \pm SD $(n=3)$.

receptors were expressed in the cell membrane of undifferentiated and differentiated Caco-2 cells (see Supporting Information section 1.7 and Figure S5C). An $80 \mathrm{kDa}$ scavenger receptor $\mathrm{B} 1$ protein was detected in both undifferentiated and differentiated cells but at higher concentration in the latter ones (Supplemental Figure S5A), while the $150 \mathrm{kDa}$ NPC1L1 protein was detected in differentiated cells only (Supplemental Figure S5B).

To check the contribution of NPC1L1 to the uptake of vitamin $\mathrm{K}$ from the micelles, ezetimibe was used as inhibitor of this receptor. ${ }^{10,22}$ In the presence of ezetimibe, the uptake of vitamin $\mathrm{K}$ in differentiated cells was only slightly reduced from $16.2 \pm 2.5$ to $13.0 \pm 1.9 \mathrm{nmol} / \mathrm{mg}$ protein for non-PEGylated micelles, and no significant changes were observed for PEGylated micelles (Figure 3A). In the presence of BLT-1 $(10 \mu \mathrm{M})$, which is an inhibitor of scavenger receptor $\mathrm{B} 1$, the uptake of vitamin $\mathrm{K}$ by differentiated cells decreased significantly from $16.2 \pm 2.5$ to $3.4 \pm 1.1 \mathrm{nmol} / \mathrm{mg}$ protein and from $9.6 \pm 0.9$ to $1.3 \pm 0.6 \mathrm{nmol} / \mathrm{mg}$ protein for nonPEGylated micelles and PEGylated micelles, respectively (Figure 3B).

Separations and Characterization of Chylomicrons. Chylomicrons are cellular components (lipoproteins) that are responsible for the excretion of lipophilic compounds including vitamin $\mathrm{K}$ to the basolateral sites of polarized endothelium. ${ }^{23}$ Although undifferentiated Caco- 2 cells can take up vitamin-K-loaded micelles (Supplemental Figure S4), they will fail to transport the taken up micelles as Caco-2 cells can secrete chylomicrons only after differentiation. ${ }^{24}$ As apolipoprotein $\mathrm{B}_{48}$ is a major protein constituent of chylomicrons, these particles can be detected and quantified by measuring $\mathrm{ApoB}_{48} \cdot{ }^{13}$ In our study, chylomicrons were isolated from lysed differentiated cells by ultracentrifugation. ${ }^{13}$ The morphology of chylomicrons was studied by TEM analysis and shown in
Figure 4A. Particle size of approximately $90 \mathrm{~nm}$ is in accordance with the size of chylomicrons as reported in the literature (with diameter above $80 \mathrm{~nm}$ ). ${ }^{13}$ The amounts of vitamin $\mathrm{K}$ and $\mathrm{ApoB}_{48}$ in the chylomicrons fraction were determined by HPLC and a sandwich ELISA kit, respectively. The amount of ApoB48 in the chylomicrons fraction was similar (194.3-204.6 ng/mg protein) for both untreated cells and cells incubated with vitamin $\mathrm{K}$ loaded mixed micelles with and without PEG coating (Figure 4B). As shown by Figure 4C, the concentration of vitamin $\mathrm{K}$ in the chylomicrons fraction was 0.29 and $0.16 \mathrm{ng} / \mathrm{mg}$ protein for cells incubated with vitamin-K-loaded mixed micelles without and with PEG coating, respectively, which is in accordance to the above observed differences in uptake using non-PEGylated and PEGylated micelles (Supplemental Figure S3).

Transport Studies. Monolayers of differentiated Caco-2 cells were used to determine the transport of vitamin $\mathrm{K}$ when formulated in different mixed micelles. TEER values are commonly used to evaluate the integrity of Caco- 2 cell monolayers, which are acceptable when the TEER value exceeds $300 \Omega \cdot \mathrm{cm}^{2} .^{25,26}$ TEER of the monolayers increased during differentiation and reached a plateau of around $900 \Omega \times \mathrm{cm}^{2}$ after 14 days (Supplemental Figure S6). To minimize adsorption of vitamin $\mathrm{K}$ onto the well plate surface ${ }^{27}$ and to increase its solubility in the medium, BSA and taurocholate were added to the basolateral HBSS medium. ${ }^{12,28-30}$ As chylomicrons play an important role in the transport of vitamin $\mathrm{K}$ by epithelium cells (see above), oleic acid was also added to the HBSS medium to induce chylomicron assembly and secretion. $^{30,31}$

To determine the extraction efficiency of vitamin $\mathrm{K}$ from the basolateral medium, known amounts of vitamin $\mathrm{K}$ in ethanol or different formulations (non-PEGylated and PEGylated micelles) were added to HBSS (at 10, 50, and $100 \mathrm{ng}$, respectively) and 

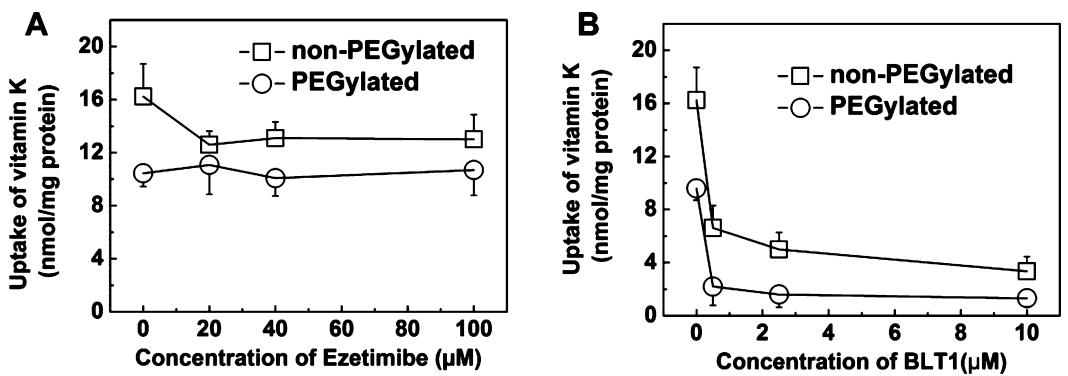

Figure 3. Effect of different concentrations of the inhibitor ezetimibe (A) and BLT-1 (B) on the uptake of vitamin-K-loaded mixed micelles $\left(1.4 \mathrm{mM}\right.$ vitamin $\mathrm{K}, 2 \mathrm{~h}$ incubation at $\left.37^{\circ} \mathrm{C}\right)$ by differentiated Caco-2 cells; results are expressed as mean $\pm \mathrm{SD}(n=3)$.
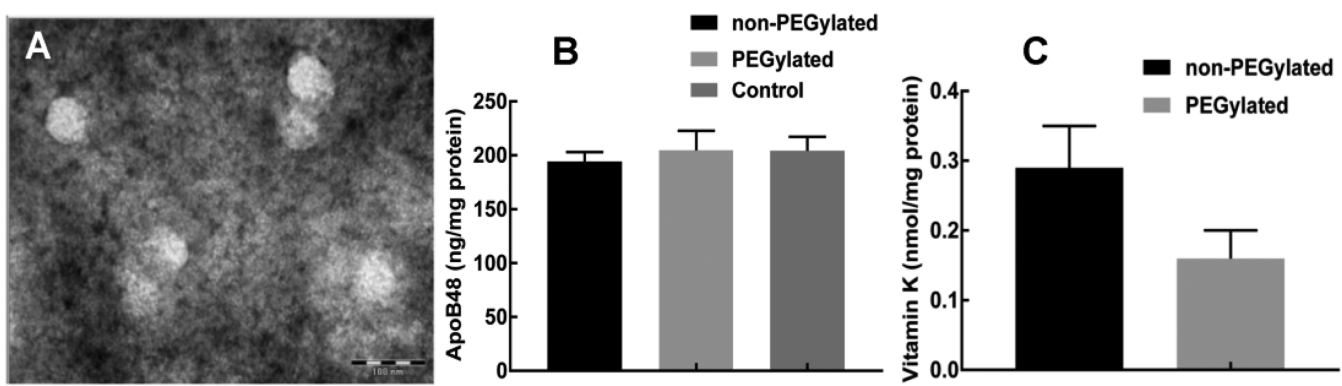

Figure 4. (A) Representative TEM image of isolated chylomicrons. Amount of $\mathrm{ApoB}_{48}$ (B) and vitamin $\mathrm{K}$ (C) per mg of cellular protein in chylomicrons.

extracted with hexane. The results of Supplemental Table S2 show that the average extraction efficiency was $83 \%$.

The effect of PEGylation of mixed micelles on the transport through monolayers of Caco- 2 cells was evaluated. The permeability coefficients were determined from the linear slope of the plots of cumulative amounts of transported vitamin $\mathrm{K}$ against time (Supplemental Figure S7) and were calculated using the equation: $P_{\text {app }}(\mathrm{cm} / \mathrm{s})=(\mathrm{d} Q / \mathrm{d} t) /\left(A C_{0}\right)$, where $\mathrm{d} Q / \mathrm{d} t$ is the steady-state flux $(\mathrm{ng} / \mathrm{s}), A$ is the surface area of the inset membrane $\left(0.33 \mathrm{~cm}^{-2}\right.$ for a 24-well plate), and $C_{0}(\mathrm{ng} / \mathrm{mL})$ is the donor concentration of vitamin $\mathrm{K}$ at the apical side. ${ }^{32}$ The permeability coefficients were $(3.2 \pm 0.3) \times 10^{-7}$ and $(1.1 \pm$ $0.5) \times 10^{-7} \mathrm{~cm} / \mathrm{s}$ for non-PEGylated micelles and PEGylated micelles, respectively (Figure 5). This means that PEGylation

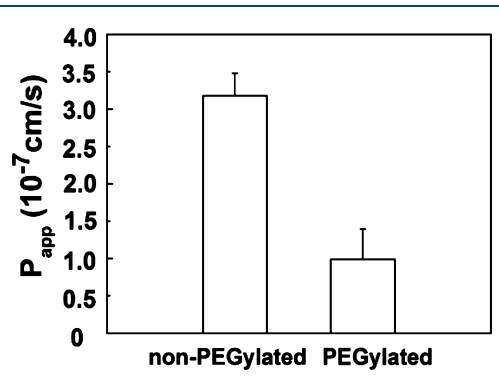

Figure 5. Permeability coefficients for the transport of vitamin $\mathrm{K}$ loaded in mixed micelles (with and without PEG coating) through Caco-2 cell monolayers; results are expressed as mean \pm SD $(n=3)$.

reduced the transport of vitamin $\mathrm{K}$ loaded in mixed micelles through Caco- 2 cell monolayers, which is in agreement with the observed reduction in uptake when micelles were PEGylated (Figure 1A).

Uptake of Vitamin K in Simulated Gastrointestinal Fluids. To mimic the in vivo fate of micelles in the gastrointestinal (GI) of pathological cholestasis conditions, mixed micelles (with and without PEG coating) were exposed to fasted simulated gastric fluid (FaSSGF) and subsequently to fasted simulated intestinal fluid (FaSSIF) without taurocholate. Two methods of collecting samples for an uptake study were conducted and compared (methods 1 and 2 as described in Uptake of Vitamin-K-Loaded Mixed Micelles by Caco-2 Cells under Simulated Gastrointestinal Conditions and illustrated in Figure 6A).

Using method 1, recovery of vitamin $\mathrm{K}$ in the supernatant from non-PEGylated mixed micelles was $47.9 \pm 6.5 \%$, indicating precipitation and a significant loss of vitamin $\mathrm{K}$ during exposure to the GI conditions. When this supernatant was added to the Caco- 2 cell monolayer, the uptake of vitamin $\mathrm{K}$ from non-PEGylated mixed micelles was reduced from around $16.2 \pm 2.5 \mathrm{nmol} / \mathrm{mg}$ protein (micelles in physiological buffer) to $1.6 \pm 0.2 \mathrm{nmol} / \mathrm{mg}$ protein (Figure $6 \mathrm{~B}$ ). However, when the treated samples were first homogenized by vortexing (method 2 ), recovery of vitamin $\mathrm{K}$ was $94.7 \pm 2.5 \%$, but the uptake was still somewhat reduced to $7.6 \pm 0.6 \mathrm{nmol} / \mathrm{mg}$ protein. Importantly, for PEGylated mixed micelles, recovery was $92 \%$ and uptake of vitamin $\mathrm{K}$ was around $8 \mathrm{nmol} / \mathrm{mg}$ protein (Figure $6 \mathrm{~B}$ ), no matter whether these micelles were exposed to the GI fluids with sampling method 1 or 2 . Moreover, uptake was similar compared to the control samples (micelles stored in physiological buffer: $9.6 \pm 0.9 \mathrm{nmol} / \mathrm{mg}$ protein).

\section{DISCUSSION}

PEG coating functions as a steric barrier and reduces the interaction between mixed micelles and the cell membrane of Caco-2 cells, explaining the reduced cellular uptake of the payload. ${ }^{33,34}$ Despite this reduction, the uptake of vitamin $\mathrm{K}$ and fluorescently labeled mixed micelles showed similar kinetics, both with and without PEG coating, and their uptake ratio (defined as rhodamine fluorescence intensity divided by the correlating uptake of vitamin K) remained constant, which indicates that micelles (with and without PEG coating) were likely taken up simultaneously with vitamin $\mathrm{K}$. A recent study 

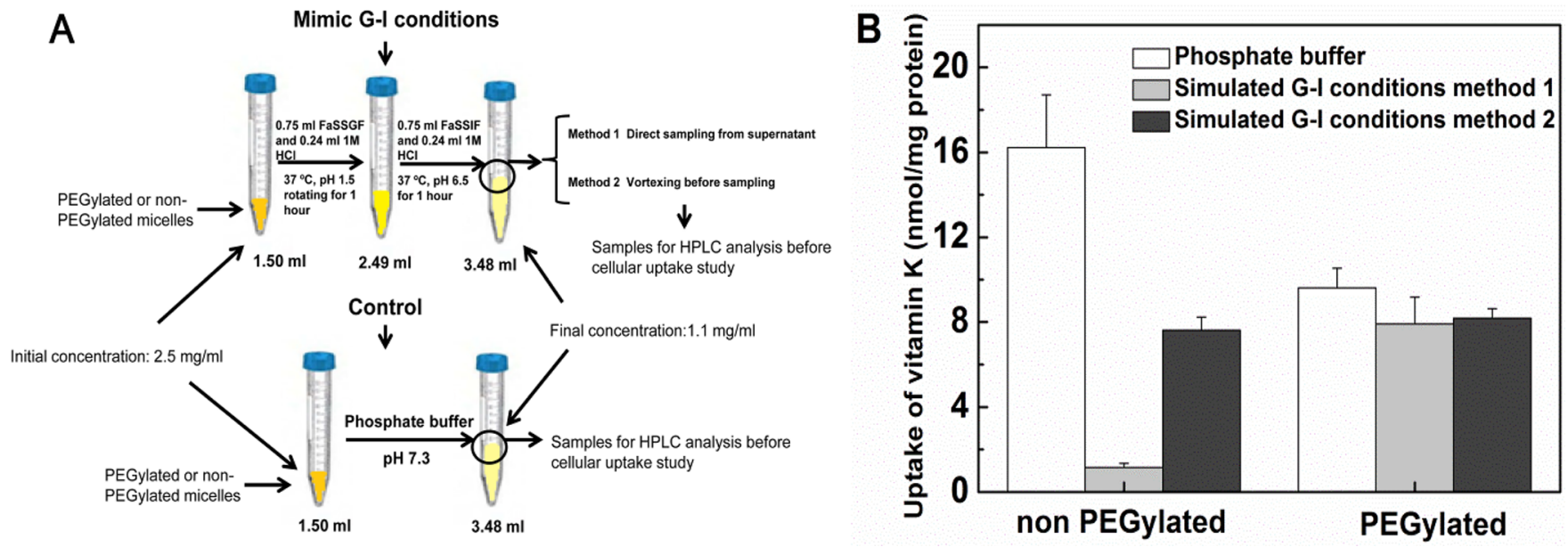

Figure 6. Schematic illustration of mimicking GI conditions (A) and uptake of vitamin $\mathrm{K}$ by Caco-2 cell monolayers upon incubation in FaSSGF (for $1 \mathrm{~h}$ ) and FaSSIF (for $1 \mathrm{~h}$ ) at $37^{\circ} \mathrm{C}$, respectively (B). As a control, mixed micelles were also directly diluted to the same concentration with phosphate buffer $(0.067 \mathrm{M}, \mathrm{pH} 7.3)$. Results are expressed as mean $\pm \mathrm{SD}(n=3)$.

also unveiled that lipid nanocapsules as well as polymeric micelles retained their integrity after crossing a human intestinal epithelium model of Caco-2 cells. ${ }^{35,36}$

Although passive diffusion is temperature dependent, ${ }^{19}$ which can to some extent also explain the reduced uptake of vitamin $\mathrm{K}$ at $4{ }^{\circ} \mathrm{C}$, our results strongly support that the concentration- and energy-dependent uptake is carrier mediated. Caco-2 cells were previously used as an epithelium model to investigate the uptake mechanism via NPC1L1, ${ }^{37-39}$ which was considered as being one of the possible receptors involved in uptake of vitamin $\mathrm{K}^{22}$ Western blot results in Supporting Information Figure S5 indeed showed the expression of NPC1L1 in the differentiated Caco- 2 cell monolayers. However, an inhibitor of NPC1L1 did not reduce the uptake of vitamin K. Together with the observation that NPC1L1 is not expressed in undifferentiated cells (Supplemental Figure S5B) while these were still able to take up the micelles (Supplemental Figure S4A), this suggests that NPC1L1 is not involved in the uptake of vitamin $\mathrm{K}$ from the micelles. Maria et al. report that scavenger receptor type $\mathrm{B} 1$ is expressed in the brush-border membrane of human enterocytes from the duodenum to the rectum. ${ }^{40}$ They also proved that SR-BI mRNA was expressed in Caco-2 cells and that its expression levels increased concomitantly with cell differentiation. ${ }^{40}$ An inhibitor of scavenger receptor B1 (BLT-1) decreased cellular uptake of vitamin $\mathrm{K}$ significantly, i.e., by $\sim 80 \%$ compared to the uptake in the absence of this inhibitor. Therefore, scavenger receptor B1 is suggested to be a main carrier that mediated the energydependent uptake of vitamin-K-loaded micelles (with and without PEG coating). In another report, it was shown that scavenger receptor type $\mathrm{B} 1$ was able to cluster in caveolae-like domains on the surfaces of cells, ${ }^{41}$ and we hypothesize that these clusters mediate the internalization of intact micelles into enterocytes via endocytosis. The presence of vitamin $\mathrm{K}$ in chylomicrons further indicates that vitamin $\mathrm{K}$ is most probably packed into chylomicrons after internalization by Caco- 2 cell monolayers.

Previous studies reported a relationship between the bioavailability and their permeability coefficients in Caco- 2 cell monolayers. ${ }^{42-44}$ Drugs that are (almost) quantitatively absorbed in humans have permeability coefficients $>1 \times 10^{-6} \mathrm{~cm} / \mathrm{s}$, drugs that are absorbed $>1 \%$ but $<100 \%$ have permeability coefficients of $0.1-1.0 \times 10^{-6} \mathrm{~cm} / \mathrm{s}$, while drugs that are essentially not absorbed $(<1 \%)$ have permeability coefficients of $<1 \times$ $10^{-7} \mathrm{~cm} / \mathrm{s}^{43}$ Based on this, the permeability coefficient of $3.2 \times 10^{-7} \mathrm{~cm} / \mathrm{s}$ as we observed for non-PEGylated micelles would have a bioavailability of around 40-60\%. Indeed, for Konakion MM the bioavailability was reported to be $27-80 \%$ with substantial inter- and intraindividual variations, ${ }^{45}$ and about $50 \%$ according to Medicine Information of Konakion MM. ${ }^{46}$ Although the permeability for the PEGylated micelles was lower than that for the non-PEGylated ones, those micelles would still provide a reasonable bioavailability of $13-20 \%$ according to these predictions.

Concentration of vitamin $\mathrm{K}$ and $\mathrm{EPC}$ in commercial Konakion $\mathrm{MM}$ (i.e., non-PEGylated micelles) is 22.4 and $100 \mathrm{mM}$, respectively. Considering dilution (20-100 times) of Konakion MM after oral dosing, we prepared vitamin-K-loaded mixed micelles at $5.6 \mathrm{mM}$ vitamin $\mathrm{K}$ and further diluted them by 425 -fold to reach similar concentrations (1.4 to $0.22 \mathrm{mM}$ ).

To simulate the conditions in the stomach, we incubated the micelles in regular FaSSGF since gastric $\mathrm{pH}$ for neonates rapidly falls within 3 to $5 \mathrm{~h}$ after birth to adult value, ${ }^{47-50}$ and full term newborns have a gastric $\mathrm{pH}$ between 1 and 3 like in the FaSSGF used in our studies. ${ }^{47}$ In vitro biorelevant simulated fluids like FaSSGF and FaSSIF are well validated in a previous study. ${ }^{18}$ To our knowledge, in newborn infants the luminal bile salt concentration is much lower than in adults (i.e., $1-5 \mathrm{mM}$ during digestion), ${ }^{51-53}$ but in our studies, bile salts were not added in FaSSIF to mimic cholestasis condition.

Further, in these in vitro simulations we did not include enzymes. Key enzymes in intestinal fat digestion are different in newborns than later in life. In newborns, the pancreas expresses low levels of colipase-dependent pancreatic triglyceride lipase. ${ }^{54}$ Pancreatic lipase-related protein 2 (PLRP2) can contribute to fat digestion during early infancy. ${ }^{55}$ Lipases could affect the micelles by hydrolysis of PEG-DSPE. In fact, cleavage of PEG from the micelles in the intestine just before the uptake by the epithelial cells will be favorable to the uptake of vitamin K. The development of in vitro intestinal lipolysis models ${ }^{56}$ will be interesting for future experiments to investigate the complex interplay of micelles with PLRP2 and other lipases.

To summarize the above, PEGylated mixed micelles displayed a two- to three-fold reduction in both cellular uptake 
and transport at neutral $\mathrm{pH}$, as compared to non-PEGylated micelles. However, this reduction was counterbalanced by the observation that the uptake of vitamin $\mathrm{K}$ from PEGylated mixed micelles increased four- to five-fold at simulated cholestatic gastrointestinal conditions because those PEGylated micelles showed good colloidal stability at this low $\mathrm{pH}$, whereas non-PEGylated mixed micelles showed coalescence and precipitation at low $\mathrm{pH}$. Apparently, once coalesced, the nonPEGylated particles are difficult to be redispersed causing poor uptake by the Caco-2 cells. This phenomenon probably explains why the non-PEGylated micelles (i.e., Konakion MM) showed poor bioavailability in human patients suffering from cholestasis. $^{3-5}$

In summary, the present study shows that scavenger receptor $\mathrm{B} 1$ participates in the absorption of vitamin $\mathrm{K}$ when loaded in both PEGylated and non-PEGylated mixed micelles probably via endocytosis of intact micelles, which are likely subsequently packed into by chylomicrons after internalization by Caco- 2 cell monolayers. Interestingly, PEGylated mixed micelles are more stable upon exposure to simulated gastrointestinal conditions, and as a result, they do show overall a higher cellular uptake efficiency of vitamin $\mathrm{K}$ as compared to mixed micelles without PEG coating in the absence of bile. Therefore, these PEGylated mixed micelles are promising formulations to be orally administrated for treatment of patients with cholestasis.

\section{ASSOCIATED CONTENT}

\section{S Supporting Information}

The Supporting Information is available free of charge on the ACS Publications website at DOI: 10.1021/acs.molpharmaceut.8b00258.

Preparation and physical (size) and chemical characterization of micelles, uptake of micelles by undifferentiated Caco-2 cells, Western blot analyses of scavenger receptor B1 and Niemann-Pick C1-like 1 (NPC1L1) expression in Caco-2 cells, measurement of trans-epithelial electroresistance (TEER) of Caco-2 cell culture, and determination of the extraction efficiency of vitamin $\mathrm{K}(\mathrm{PDF})$

\section{AUTHOR INFORMATION}

\section{Corresponding Author}

*Tel: + 31 620274607. Fax: +31 30 2517839. E-mail: C.F. vanNostrum@uu.nl.

\section{ORCID}

Lukas C. Kapitein: 0000-0001-9418-6739

Wim E. Hennink: 0000-0002-5750-714X

Cornelus F. van Nostrum: 0000-0003-4210-5241

Notes

The authors declare no competing financial interest.

\section{ACKNOWLEDGMENTS}

F.S. was supported by a personal research grant from China Scholarship Council.

\section{ABBREVIATIONS}

VKDB, vitamin $\mathrm{K}$ deficiency bleeding; EPC, egg phosphatidylcholine (lecithin); DSPE-PEG 2000, 1,2-distearoyl-snglycero-3-phosphoethanolamine- $N$-[methoxy(polyethylene glycol)-2000]; MM, mixed micelles; BLT-1, block lipid transport-1; NPC1L1, Niemann-Pick C1-like 1; FBS, fetal bovine serum; DLS, dynamic light scattering; FACS, fluorescence activated cell sorting analysis; TEER, transepithelial electroresistance; PDI, polydispersity index; TEM, transmission electron microscopy; HBSS, Hank's balanced salt solution; GI, gastrointestinal; FaSSGF, fasted simulated gastric fluid; FaSSIF, fasted simulated intestinal fluid

\section{REFERENCES}

(1) Lippi, G.; Franchini, M. Vitamin K in neonates: facts and myths. Blood Transfus. 2011, 9 (1), 4-9.

(2) Iqbal, J.; Hussain, M. M. Intestinal lipid absorption. Am. J. Physiol. Endocrinol. Metab. 2009, 296 (6), E1183-E1194.

(3) Van Hasselt, P. M.; Kok, K.; Vorselaars, A. D.; van Vlerken, L.; Nieuwenhuys, E.; de Koning, T. J.; de Vries, R. A.; Houwen, R. H. Vitamin $\mathrm{K}$ deficiency bleeding in cholestatic infants with alpha-1antitrypsin deficiency. Arch. Dis. Child. Fetal. Neonatal Ed. 2009, 94 (6), F456-F460.

(4) Pereira, S.; Shearer, M.; Williams, R.; Mieli-Vergani, G. Intestinal absorption of mixed micellar phylloquinone (vitamin $\mathrm{K} 1$ ) is unreliable in infants with conjugated hyperbilirubinaemia: implications for oral prophylaxis of vitamin $\mathrm{K}$ deficiency bleeding. Arch. Dis. Child. Fetal. Neonatal Ed. 2003, 88 (2), F113-F118.

(5) Van Hasselt, P. M.; de Koning, T. J.; Kvist, N.; de Vries, E.; Lundin, C. R.; Berger, R.; Kimpen, J. L.; Houwen, R. H.; Jorgensen, M. H.; Verkade, H. J. Prevention of vitamin K deficiency bleeding in breastfed infants: lessons from the Dutch and Danish biliary atresia registries. Pediatrics 2008, 121 (4), e857-e863.

(6) Glycocholic Acid, Sodium Salt data sheet from EMD Millipore Corporation, Billerica, USA. Available from: http://www. merckmillipore.com/NL/en/product/Glycocholic-Acid-Sodium-SaltCAS-863-57-0-Calbiochem,EMD BIO-360512?ReferrerURL= https\%3A\%2F\%2Fwww.google.com\% $2 \mathrm{~F} \& \mathrm{bd}=1$ (assessed in 2017).

(7) Van Hasselt, P. M. Vitamin K prophylaxis revisited: Focus on risk factors. Thesis, Utrecht University, Utrecht, 2009.

(8) Sun, F.; Jaspers, T. C.; van Hasselt, P. M.; Hennink, W. E.; van Nostrum, C. F. A Mixed Micelle Formulation for Oral Delivery of Vitamin K. Pharm. Res. 2016, 33 (9), 2168-2179.

(9) Gijsbers, B. L.; Jie, K. S. G.; Vermeer, C. Effect of food composition on vitamin $\mathrm{K}$ absorption in human volunteers. Br. J. Nutr. 1996, 76 (02), 223-229.

(10) Goncalves, A.; Margier, M.; Roi, S.; Collet, X.; Niot, I.; Goupy, P.; Caris-Veyrat, C.; Reboul, E. Intestinal scavenger receptors are involved in vitamin K1 absorption. J. Biol. Chem. 2014, 289 (44), 30743-30752.

(11) Winn, M.; White, P.; Scott, A.; Pratt, S.; Park, B. The bioavailability of a mixed micellar preparation of vitamin $\mathrm{K} 1$, and its procoagulant effect in anticoagulated rabbits. J. Pharm. Pharmacol. 1989, 41 (4), 257-260.

(12) Hubatsch, I.; Ragnarsson, E. G. E.; Artursson, P. Determination of drug permeability and prediction of drug absorption in Caco-2 monolayers. Nat. Protoc. 2007, 2 (9), 2111-2119.

(13) Nauli, A. M.; Sun, Y.; Whittimore, J. D.; Atyia, S.; Krishnaswamy, G.; Nauli, S. M. Chylomicrons produced by Caco-2 cells contained ApoB-48 with diameter of 80-200 nm. Physiol. Rep. 2014, 2 (6), e12018.

(14) Luchoomun, J.; Hussain, M. M. Assembly and secretion of chylomicrons by differentiated Caco- 2 cells. Nascent triglycerides and preformed phospholipids are preferentially used for lipoprotein assembly. J. Biol. Chem. 1999, 274, 19565-19572.

(15) Terpstra, A. Isolation of serum chylomicrons prior to density gradient ultracentrifugation of other serum lipoprotein classes. Anal. Biochem. 1985, 150, 221-227.

(16) Cogburn, J. N.; Donovan, M. G.; Schasteen, C. S. Correlation of Caco-2 transport with human oral bioavailability. J. Controlled Release 1990, 13, 314-315.

(17) Lechanteur, A.; Almeida, A.; Sarmento, B. Elucidation of the impact of cell culture conditions of Caco-2 cell monolayer on barrier 
integrity and intestinal permeability. Eur. J. Pharm. Biopharm. 2017, 119, 137-141.

(18) Klein, S. The use of biorelevant dissolution media to forecast the in vivo performance of a drug. AAPS J. 2010, 12 (3), 397-406.

(19) Sugano, K.; Kansy, M.; Artursson, P.; Avdeef, A.; Bendels, S.; Di, L.; Ecker, G. F.; Faller, B.; Fischer, H.; Gerebtzoff, G.; Lennernaes, H.; Senner, F. Coexistence of passive and carrier-mediated processes in drug transport. Nat. Rev. Drug Discovery 2010, 9 (8), 597-614.

(20) Ravi, P. R.; Aditya, N.; Kathuria, H.; Malekar, S.; Vats, R. Lipid nanoparticles for oral delivery of raloxifene: optimization, stability, in vivo evaluation and uptake mechanism. Eur. J. Pharm. Biopharm. 2014, 87, 114-124.

(21) Lind, M. L.; Jacobsen, J.; Holm, R.; Müllertz, A. Intestinal lymphatic transport of halofantrine in rats assessed using a chylomicron flow blocking approach: the influence of polysorbate 60 and 80. Eur. J. Pharm. Sci. 2008, 35 (3), 211-218.

(22) Takada, T.; Yamanashi, Y.; Konishi, K.; Yamamoto, T.; Toyoda, Y.; Masuo, Y.; Yamamoto, H.; Suzuki, H. NPC1L1 is a key regulator of intestinal vitamin $\mathrm{K}$ absorption and a modulator of warfarin therapy. Sci. Transl. Med. 2015, 7 (275), 275ra23-ra23.

(23) Shearer, M. J.; Newman, P. Recent trends in the metabolism and cell biology of vitamin $\mathrm{K}$ with special reference to vitamin $\mathrm{K}$ cycling and MK-4 biosynthesis. J. Lipid Res. 2014, 55 (3), 345-362.

(24) Luchoomun, J.; Zhou, Z.; Bakillah, A.; Jamil, H.; Hussain, M. $\mathrm{M}$. Assembly and secretion of VLDL in nondifferentiated Caco-2 cells stably transfected with human recombinant ApoB48 cDNA. Arterioscler. Arterioscler., Thromb., Vasc. Biol. 1997, 17 (44), 29552963.

(25) Lo, Y. L. Relationships between the hydrophilic-lipophilic balance values of pharmaceutical excipients and their multidrug resistance modulating effect in Caco-2 cells and rat intestines. $J$. Controlled Release 2003, 90 (44), 37-48.

(26) Zeng, Z.; Shen, Z. L.; Zhai, S.; Xu, J. L.; Liang, H.; Shen, Q.; Li, Q. Y. Transport of curcumin derivatives in Caco-2 cell monolayers. Eur. J. Pharm. Biopharm. 2017, 117, 123-131.

(27) Broeders, J. J.; van Eijkeren, J. C.; Blaauboer, B. J.; Hermens, J. L. Transport of chlorpromazine in the Caco- 2 cell permeability assay: a kinetic study. Chem. Res. Toxicol. 2012, 25 (7), 1442-1451.

(28) Saha, P.; Kou, J. H. Effect of bovine serum albumin on drug permeability estimation across Caco-2 monolayers. Eur. J. Pharm. Biopharm. 2002, 54 (3), 319-324.

(29) Yamashita, S.; Furubayashi, T.; Kataoka, M.; Sakane, T.; Sezaki, H.; Tokuda, H. Optimized conditions for prediction of intestinal drug permeability using Caco-2 cells. Eur. J. Pharm. Sci. 2000, 10 (3), 195204.

(30) Anwar, K.; Kayden, H. J.; Hussain, M. M. Transport of vitamin E by differentiated Caco-2 cells. J. Lipid Res. 2006, 47 (6), 12611273.

(31) Moberly, J. B.; Cole, T. G.; Alpers, D. H.; Schonfeld, G. Oleic acid stimulation of apolipoprotein B secretion from HepG2 and Caco2 cells occurs post-transcriptionally. Biochim. Biophys. Acta, Lipids Lipid Metab. 1990, 1042 (44), 70-80.

(32) Gantzsch, S. P.; Kann, B.; Ofer-Glaessgen, M.; Loos, P.; Berchtold, H.; Balbach, S.; Eichinger, T.; Lehr, C. M.; Schaefer, U. F.; Windbergs, M. Characterization and evaluation of a modified PVPA barrier in comparison to Caco-2 cell monolayers for combined dissolution and permeation testing. J. Controlled Release 2014, 175, 79-86.

(33) Zhao, C.; Deng, H.; Xu, J.; Li, S.; Zhong, L.; Shao, L.; Wu, Y.; Liang, X. J. Sheddable" PEG-lipid to balance the contradiction of PEGylation between long circulation and poor uptake. Nanoscale 2016, 8 (20), 10832-10842.

(34) Bao, Y.; Jin, Y.; Chivukula, P.; Zhang, J.; Liu, Y.; Liu, J.; Clamme, J. P.; Mahato, R. I.; Ng, D.; Ying, W.; Wang, Y.; Yu, L. Effect of PEGylation on biodistribution and gene silencing of siRNA/lipid nanoparticle complexes. Pharm. Res. 2013, 30, 342-351.

(35) Roger, E.; Gimel, J. C.; Bensley, C.; Klymchenko, A. S.; Benoit, J. P. Lipid nanocapsules maintain full integrity after crossing a human intestinal epithelium model. J. Controlled Release 2017, 253, 11-18.
(36) Parayath, N. N.; Nehoff, H.; Müller, P.; Taurin, S.; Greish, K. Styrene maleic acid micelles as a nanocarrier system for oral anticancer drug delivery-dual uptake through enterocytes and Mcells. Int. J. Nanomed. 2015, 10, 4653-4667.

(37) Feng, D.; Ohlsson, L.; Duan, R.-D. Curcumin inhibits cholesterol uptake in Caco-2 cells by down-regulation of NPC1L1 expression. Lipids Health Dis. 2010, 9 (1), 40.

(38) During, A.; Dawson, H. D.; Harrison, E. H. Carotenoid transport is decreased and expression of the lipid transporters SR-BI, NPC1L1, and ABCA1 is downregulated in Caco-2 cells treated with ezetimibe. J. Nutr. 2005, 135 (10), 2305-2312.

(39) Nekohashi, M.; Ogawa, M.; Ogihara, T.; Nakazawa, K.; Kato, H.; Misaka, T.; Abe, K.; Kobayashi, S. Luteolin and quercetin affect the cholesterol absorption mediated by epithelial cholesterol transporter Niemann-Pick C1-Like 1 in caco-2 cells and rats. PLoS One 2014, 9 (5), e97901.

(40) Lobo, M. V.; Huerta, L.; Ruiz-Velasco, N.; Teixeiro, E.; de la Cueva, P.; Celdrán, A.; Martín-Hidalgo, A.; Vega, M. A.; Bragado, R. Localization of the lipid receptors CD36 and CLA-1/SR-BI in the human gastrointestinal tract: towards the identification of receptors mediating the intestinal absorption of dietary lipids. J. Histochem. Cytochem. 2001, 49 (10), 1253-1260.

(41) Krieger, M. Charting the fate of the "good cholesterol": identification and characterization of the high-density lipoprotein receptor SR-BI. Annu. Rev. Biochem. 1999, 68, 523-558.

(42) Marinova, M.; Lütjohann, D.; Breuer, O.; Kölsch, H.; Westhofen, P.; Watzka, M.; Mengel, M.; Stoffel-Wagner, B.; Hartmann, G.; Coch, C.; Oldenburg, J. VKORC1-dependent pharmacokinetics of intravenous and oral phylloquinone (vitamin K1) mixed micelles formulation. Eur. J. Clin. Pharmacol. 2013, 69 (3), 467-475.

(43) Artursson, P.; Karlsson, J. Correlation between oral drug absorption in humans and apparent drug permeability coefficients in human intestinal epithelial (Caco-2) cells. Biochem. Biophys. Res. Commun. 1991, 175 (3), 880-885.

(44) Grès, M. C.; Julian, B.; Bourrié, M.; Meunier, V.; Roques, C.; Berger, M.; Boulenc, X.; Berger, Y.; Fabre, G. Correlation between oral drug absorption in humans, and apparent drug permeability in TC-7 cells, a human epithelial intestinal cell line: comparison with the parental Caco-2 cell line. Pharm. Res. 1998, 15 (5), 726-733.

(45) Marinova, M.; Lütjohann, D.; Breuer, O.; Kölsch, H.; Westhofen, P.; Watzka, M.; Mengel, M.; Stoffel-Wagner, B.; Hartmann, G.; Coch, C.; Oldenburg, J. VKORC1-dependent pharmacokinetics of intravenous and oral phylloquinone (vitamin K1) mixed micelles formulation. Eur. J. Clin. Pharmacol. 2013, 69 (3), 467-475.

(46) Konakion MM Paediatric, Summary of Product Characteristics. Roche Products Limited. Available from: https://www.medicines.org. $\mathrm{uk} / \mathrm{emc} /$ print-document?documentId=1699 (assessed in 2015).

(47) Tayman, C.; Rayyan, M.; Allegaert, K. Neonatal pharmacology: extensive interindividual variability despite limited size. J. Pediatr. Pharmacol. Ther. 2011, 16 (3), 170-184.

(48) Ménard, D. Functional development of the human gastrointestinal tract: hormone-and growth factor-mediated regulatory mechanisms. Can. J. Gastroenterol. Hepatol. 2004, 18 (1), 39-44.

(49) Lebenthal, A.; Lebenthal, E. The ontogeny of the small intestinal epithelium. JPEN, J. Parenter. Enteral Nutr. 1999, 23 (5 suppl), S3-S6.

(50) Kelly, E.; Newell, S.; Brownlee, K.; Primrose, J.; Dear, P. Gastric acid secretion in preterm infants. Early Hum. Dev. 1993, 35 (3), 215-220.

(51) Andersson, E. L.; Hernell, O.; Blackberg, L.; Falt, H.; Lindquist, S. BSSL and PLRP2: key enzymes for lipid digestion in the newborn examined using the Caco-2 cell line. J. Lipid Res. 2011, 52 (11), 1949-1956.

(52) Watkins, J. B. Bile acid metabolism and fat absorption in newborn infants. Pediatr. Clin. North Am. 1974, 21 (2), 501-512. 
(53) Järvenpää, A.-L.; Rassin, D.; Kuitunen, P.; Gaull, G.; Räihä, N. Feeding the Low-Birth-Weight Infant III. Diet Influences Bile Acid Metabolism. Pediatrics 1983, 72 (5), 677-683.

(54) Johnson, K.; Ross, L.; Miller, R.; Xiao, X.; Lowe, M. E. Pancreatic lipase-related protein 2 digests fats in human milk and formula in concert with gastric lipase and carboxyl ester lipase. Pediatr. Res. 2013, 74 (2), 127-132.

(55) Xiao, X.; Mukherjee, A.; Ross, L. E.; Lowe, M. E. Pancreatic lipase-related protein-2 (PLRP2) can contribute to dietary fat digestion in human newborns. J. Biol. Chem. 2011, 286 (30), 26353-26363.

(56) Mosgaard, M. D.; Sassene, P.; Mu, H.; Rades, T.; Müllertz, A. Development of a high-throughput in vitro intestinal lipolysis model for rapid screening of lipid-based drug delivery systems. Eur. J. Pharm. Biopharm. 2015, 94, 493-500. 